\title{
The effects of low dose X-irradiation on osteoblastic MC3T3-E1 cells in vitro
}

\author{
Wei $\mathrm{Xu}^{1+}$, Lan $\mathrm{Xu}^{2 \dagger}$, Ming Chen ${ }^{1}$, Yong Tao Mao ${ }^{1}$, Zong Gang Xie', Shi Liang Wu² and Qi Rong Dong ${ }^{1 *}$
}

\begin{abstract}
Background: It has been indicated that moderate or high dose of X-irradiation could delay fracture union and cause osteoradionecrosis, in part, mediated by its effect on proliferation and differentiation of osteoblasts. However, whether low dose irradiation (LDI) has similar roles on osteoblasts is still unknown. In this study, we investigated whether and to what extent LDI could affect the proliferation, differentiation and mineralization of osteoblasts in vitro.

Methods: The MC3T3-E1 cells were exposed to single dose of X-irradiation with 0, 0.1, 0.5, 1.0 Gy respectively. Cell proliferation, apoptosis, alkaline phosphatase (ALP) activity, and mineralization was evaluated by methylthiazoletetrazolium (MTT) and bromodeoxyuridine (BrdU) assay, flow cytometry, ALP viability kit and von Kossa staining, respectively. Osteocalcin (OCN) and core-binding factor a1 (Cbfa1) expressions were measured by real time-PCR and western blot, respectively.

Results: The proliferation of the cells exposed to $2.0 \mathrm{~Gy}$ was significantly lower than those exposed to $\leq 1.0 \mathrm{~Gy}$ $(p<0.05)$ from Day 4 to Day 8, measured by MTT assay and BrdU incorporation. For cells exposed to $\leq 1.0 \mathrm{~Gy}$, increasing dosages of $\mathrm{X}$-irradiation had no significant effect on cell proliferation and apoptosis. Importantly, LDI of 0.5 and 1 Gy increased ALP activities and mineralized nodules of MC3T3-E1 cells. In addition, mRNA and protein expressions of OCN and Cbfa1 were also markedly increased after treatment with LDI at 0.5 and 1 Gy.

Conclusions: LDI have different effects on proliferation and differentiation of osteoblasts from those of high dose of X-irradiation, which might suggest that LDI could lead to promotion of frature healing through enhancing the differentiation and mineralization of osteoblasts.
\end{abstract}

Keywords: Low dose irradiation, Osteoblasts, Proliferation, Differentiation

\section{Background}

Ionizing radiation was a common therapy in the treatment of cancer, especially the head and neck carcinomas. Despite of its therapeutic value, osteoradionecrosis was considered to be one of the most serious clinical complications after radiation therapy [1]. However, as we know, the dosage of ionizing radiation was usually moderate or high in the application of cancer therapy.

Clinically, patients with fractures were often exposed to CT scan before surgery, fluoroscopy during operation and X-ray during follow-up postoperatively, where they received irradiation dose usually $\leq 1$ Gy [2-4]. It meant

\footnotetext{
* Correspondence: dongarszgk@gmail.com

${ }^{\dagger}$ Equal contributors

'Department of Orthopedics, The Second Affiliated Hospital of Soochow University, Suzhou 215004, China

Full list of author information is available at the end of the article
}

that injured bone tissues might exist when exposed to low dose irradiation (LDI). But there were limited studies on the effects of LDI on the healing and remodeling of bone tissues. To understand this, our preliminary studies surprisingly showed that LDI could promote fracture mineralization in Sprague-Dawley rat model [5]. It was generally considered that ordered proliferation and differentiation of osteoblast was indispensable for mineralization of extracellular matrix in bone formation during wound healing [6]. To our knowledge, LDI had several biologic effects of increasing expression of vascular endothelial growth factor (VEGF) and mobilization of progenitor cells $[7,8]$.

In the light of this, the major objective of this study was to explore the molecular mechanism of effects of LDI on healing and remodeling of bone tissues, and to examine whether and to what extent LDI could

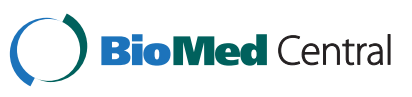


influence the proliferation and differentiation processes of the osteoblastic-like cell line (MC3T3-E1). As a consequence, our findings would be beneficial for further understanding the underlying cellular and molecular mechanisms of the potential roles of LDI on fracture healing.

\section{Methods}

\section{Cell culture}

MC3T3-E1 cells were provided by the Institute of Biochemistry and Cell Biology, China. The cells were cultured in $\alpha$-MEM medium consisting of 10\% FBS, $5 \mathrm{mM}$ $\beta$-glycerophosphate, $50 \mu \mathrm{g} / \mathrm{ml} \mathrm{L-ascorbic} \mathrm{acid} \mathrm{(Sigma,}$ USA) as described by Yamasaki et al [9]. The culture medium was changed every three days. After cells had reached $70 \%$ confluence, cells were detached by treatment with $0.05 \%$ trypsin, and replated for experiments. Low passage frozen stocks were prepared and early passage cells were used in the experiments (less than passage 10).

\section{Irradiation of osteoblastic cells}

MC3T3-E1 cells were irradiated respectively with 0 (as the control), 0.1, 0.5 and 1.0 Gy X-irradiation (at a dose rate of $200 \mathrm{cGy} / \mathrm{min}$ ) by a medical linear accelerator with a $6 \mathrm{MV}$ radiation source (Siemens Primus, Concord, CA, USA) on the next day after being seeded (day 0 ).

\section{Proliferation assay}

Cells were plated at a density of $1 \times 10^{3}$ cells/well into 96-well plates for cell growth assay. The methylthiazoletetrazolium (MTT, Sigma) assay was performed from Day 2 to Day 8 as described by Carmichael et al. [10]. In brief, $20 \mu \mathrm{l} \mathrm{MTT}(5 \mathrm{mg} / \mathrm{ml}$ ) was added to the wells and the plate was incubated at $37^{\circ} \mathrm{C}$ for $4 \mathrm{~h}$. Subsequently, $100 \mu \mathrm{l}$ of dimethyl sulphoxide was added to release the formed formazan crystals from the living cells' mitochondria into the solution. Optical density (OD) was measured at $495 \mathrm{~nm}$ and automatically calculated as absorbance using the microplate scanning spectrophotometer (POWERWAVE.XS, Bio-Tek, USA).

Cell proliferation was also determined by bromodeoxyuridine $(\mathrm{BrdU})$ incorporation analysis. Cells were plated in 96-well plates $\left(1 \times 10^{3}\right.$ cells/well) and the BrdU incorporation in the new synthesized DNA was quantified as described by Kanazawa et al. [11]. Briefly, BrdU (Roche, Germany) was added to the medium for $2 \mathrm{~h}$. After removal of the culture medium, the cells were fixed and the DNA was denatured. Anti-BrdU antibody was then added to measure the amount of incorporated BrdU. Absorbance of each well was measured using the microplate scanning spectrophotometer at $450 \mathrm{~nm}$.

\section{Apoptosis analysis}

Cells were plated at a density of $5 \times 10^{4}$ cells/well into 6well plates. Apoptosis of MC3T3-E1 cells were evaluated by flow cytometery. Cells were collected and detected using the annexin V-FITC/PI apoptosis detection kit (Molecular Probes, USA) as described by $\mathrm{Xu}$ et al. [12]. In brief, cells were collected and resuspended in $1 \times$ cold binding buffer (10 mM Hepes, pH 7.4, $150 \mathrm{mM} \mathrm{NaCl}$, $2.5 \mathrm{mM} \mathrm{CaCl}_{2}, 1 \mathrm{mM} \mathrm{MgCl}, 4 \% \mathrm{BSA}$ ) for analysis. Cells were also stained with PI to detect late apoptosis cells. 10,000 cells were subjected to flow cytometric analysis.

\section{Assay of alkaline phosphatase activity and alkaline phosphatase staining}

Cells were plated at a density of $2 \times 10^{4}$ cells/well into 24- well plates. The cells were cultured for 7 days after irradiation, rinsed three times with PBS, and $600 \mu \mathrm{l}$ of distilled water were added to each well and sonicated. The protein assay was performed with the bicinchoninic acid (BCA) protein assay reagent (Sigma). ALP activity was assayed by a method modified from that of Lowry et al. [13]. In brief, the assay mixtures contained $0.1 \mathrm{M}$ 2-amino-2-methyl-1-propanol, $1 \mathrm{mM} \mathrm{MgCl}_{2}, 8 \mathrm{mM}$ pnitrophenyl phosphate disodium, and cell homogenates. After incubation for $4 \mathrm{~min}$ at $37^{\circ} \mathrm{C}$, the reaction was stopped with $0.1 \mathrm{~N} \mathrm{NaOH}$, and the absorbance was read at $405 \mathrm{~nm}$. Each value was expressed as p-nitrophenol produced in nanomoles per minute per microgram of protein.

Similarly, ALP staining was also performed by a standard protocol on day 7 after irradiation. In brief, cells were fixed in $100 \%$ methanol and overlaid with $1.5 \mathrm{ml}$ of $0.15 \mathrm{mg} / \mathrm{ml}$ 5-bromo-4-chloro-3-indolyphosphate plus $0.3 \mathrm{mg} / \mathrm{ml}$ nitroblue tetrazolium chloride in $0.1 \mathrm{M}$ Tris$\mathrm{HCl}, \mathrm{pH}$ 9.5, $0.01 \mathrm{~N} \mathrm{NaOH}$, and $0.05 \mathrm{M} \mathrm{MgCl}_{2}$, followed by incubation at room temperature for $2 \mathrm{~h}$ in the dark.

\section{Assay of mineralization}

The mineralization of MC3T3-E1 cells was determined in 6 -well $\left(1 \times 10^{5}\right.$ cells/well) using von Kossa staining on day 14 after irradiation. Cells were added by $1 \%$ silver nitrate and put in the dark place for $45 \mathrm{~min}$. Then, cells were washed for $10 \mathrm{~min}$ and added by $95 \%$ sodium thiosulfate to react for $5 \mathrm{~min}$, fixed with $95 \%$ ethanol for $10 \mathrm{~min}$. Mineralized nodules stained with dark brown to black dots were counted at $30 \times$ magnification using a dissecting microscope by placing the culture plate upon a transparent acetate grid ruled in $2 \mathrm{~mm}$ squares as described by Bellows et al [14].

\section{Real-time PCR quantification for mRNA expression of osteocalcin (OCN), core-binding factor a1 (Cbfa1)}

Cells were seeded at a density of $1 \times 10^{5}$ cells/well into 6-well plates. On day 10 after irradiation, the total 
RNA was extracted with Trizol reagent (Gibco, USA) and cDNA was synthesized with the reverse transcription kit (TakaRa, China). SYBR green chemistry (Toyobo, Japan) was used to perform quantitative determination for the mRNAs for OCN, Cbf $\alpha 1, \beta$-actin was used as endogenous control. Primer sequences were showed as followed: OCN forward primer, 5'CTGGCTGCGCTCTGTCTCT-3'; reverse primer, 5'TGCTTGGACATGAAGGCTTTG -3'. Cbf 1 forward primer, 5' - AAGTGCGGTGCAAACTTTCT -3'; reverse primer, 5'- TCTCGGTGGCTGGTAGTGA - 3 '. $\beta$-actin forward primer, 5' - CTGGCACCACACCTTCTACA -3'; reverse primer, 5'- GGTACGACCAGAGGCATACA -3'. Analysis was performed with ABI PRISM 7000 (PE Applied Biosystems Inc). Reaction condition was $95^{\circ} \mathrm{C}$ for $15 \mathrm{~min}, 40$ cycles of denaturation at $94^{\circ} \mathrm{C}$ for $15 \mathrm{~s}$, and annealing and extension at $60^{\circ} \mathrm{C}$ for $1 \mathrm{~min}$. The mRNA expression of $\mathrm{OCN}$ and $\mathrm{Cbf} \alpha 1$ was normalized to endogenous control and relative to a calibrator, and was calculated using formula as described by Livak et al. [15]. Results were expressed as fold change in gene expression relative to the control group (0 Gy).

\section{Western-blot analysis for protein expression of OCN, Cbfa1}

Cells were seeded at a density of $1 \times 10^{5}$ cells/well into 6well plates and the irradiated cells were cultured steadily for 10 days. Cells were incubated with $300 \mu$ of lysis buffer ( $1 \%$ NP-40, $0.5 \%$ deoxycholate, $0.1 \%$ SDS) on ice for $30 \mathrm{~min}$. The lysate was centrifuged at $14000 \mathrm{rpm}$, the supernatant was collected and protein concentration was determined by the Bicinchoninine acid assay, meanwhile the standard curve was mapped. Equally, $20 \mu \mathrm{g}$ of crude protein extracts for every sample were loaded to $10 \%$ sodium dodecyl sulphate-polyacrylamide gels, and then transferred onto nitrocellulose membranes. The membrane was incubated overnight with primary monoclonal antibodies rabbit anti-mice OCN (diluted 1:1000, R\&D, USA), Cbf $\alpha 1$ (diluted 1:1000, R\&D, USA) and $\beta$-actin (diluted 1:800, Santa Cruz, USA). After washing three times, the samples were continually incubated with the HRPconjugated goat anti-rabbit IgG-AP (1:2000) for $60 \mathrm{~min}$. The protein was visualized using the BM Chemiluminescence Western Blotting Kit (Boehringer, Mannheim, Germany) according to the manufacturer's protocol.

\section{Statistical analysis}

Each experiment was repeated independently three times and all data were expressed as mean \pm SD. Analyses of variance (one-way ANOVA) were performed using SPSS 17.0. $P$ value less than 0.05 was considered significant.

\section{Results}

Effects of irradiation on proliferation of MC3T3-E1 cells

The relative proliferation rate of the cells exposed to 2.0 Gy was significantly lower than those exposed to $\leq 1.0$ Gy $(\mathrm{p}<0.05)$ from Day 4 to Day 8 , measured by MTT assay. For cells exposed to $\leq 1.0 \mathrm{~Gy}$, Increasing dosages of X-irradiation had no effects on relative proliferation rates of MC3T3-E1 cells from day 2 to day 7. On day 8 , relative proliferation rate of cells exposed to 0.5 and $1 \mathrm{~Gy}$ was lower than that of the control and 0.1 Gy groups $(\mathrm{p}<0.05)$ (Figure 1). Interestingly, cell proliferation was reduced on Day 8 when compared to Day 6

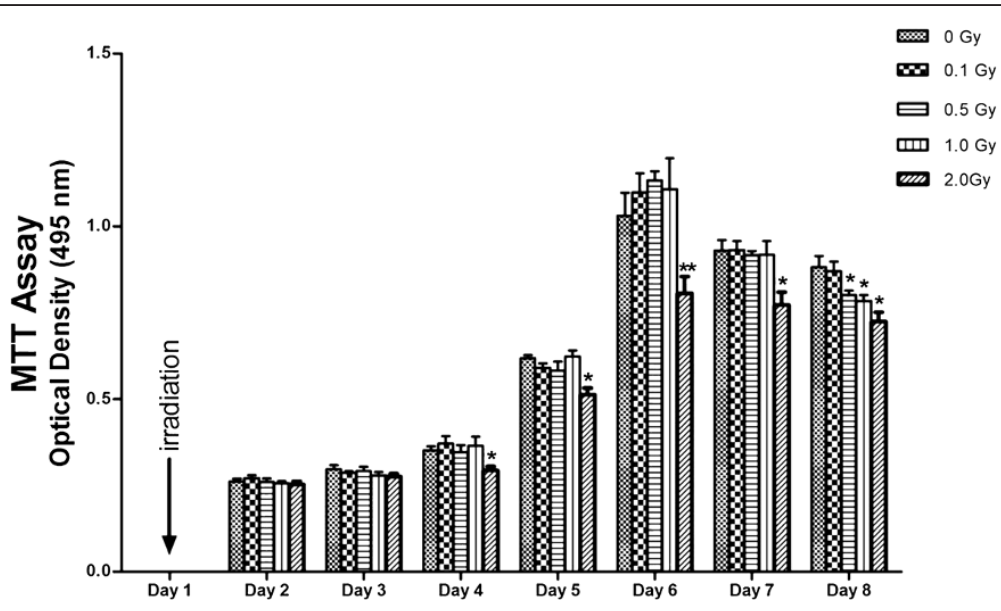

Figure 1 Growth curve of irradiated MC3T3-E1 cells assessed by MTT assay. MC3T3-E1 cells were exposed to 0, 0.1, 0.5, 1.0 and 2.0 Gy of X-ray irradiation respectively. The effect of irradiation on cell growth was assessed by MTT assay at 24-h intervals until day 8 after been seeded. Optical density (OD) was measured at $495 \mathrm{~nm}$ and data were expressed as the mean \pm SD of triplicate experiments $(n=3)$. From day 4 to day 8 , relative proliferation rate of the cells exposed to $2.0 \mathrm{~Gy}$ was significantly lower than those of the control group $(0 \mathrm{~Gy})\left({ }^{*} p<0.05,{ }^{* *} p<0.01\right)$. On day 8, relative proliferation rates of the cells exposed to 0.5 and 1 Gy were lower than those of the control group and 0.1 Gy group $\left(^{*} p<0.05\right)$. 


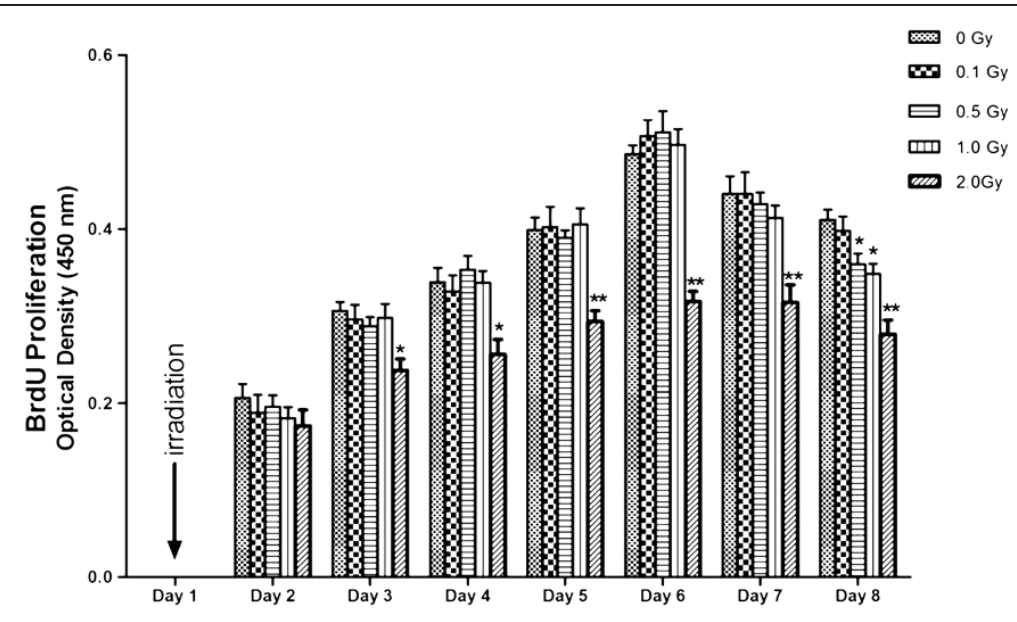

Figure 2 Proliferation of MC3T3-E1 cells after irradiation assessed by BrdU incorporation assay. MC3T3-E1 cells were exposed to $0,0.1,0.5$, 1.0 and 2.0 Gy of X-ray irradiation respectively. Cell proliferation was determined by BrdU incorporation assay at 24-h intervals until day 8 after been seeded. Absorbance in each well was measured at $450 \mathrm{~nm}$ and data were expressed as the mean \pm SD of triplicate experiments $(n=3)$. From day 3 to day 8, the DNA synthesis of the cells exposed to 2.0 Gy was significantly lower than those of the control group $(0 \mathrm{~Gy})\left({ }^{*} p<0.05,{ }^{* *} p<0.01\right)$. On day 8, the DNA synthesis of the cells exposed to 0.5 and 1 Gy were lower than those of the control group and 0.1 Gy group $\left(^{*} p<0.05\right)$.

(data not shown). The BrdU uptake results was similar to MTT assay (Figure 2).

\section{Effects of irradiation on apoptosis of MC3T3-E1 cells}

To ascertain whether proliferation changes on day 6-8 were linked to apoptosis, we evaluated cell apoptosis. Data of apoptosis showed that there was no statistically significant difference among groups exposed to $\leq 1.0$ Gy irradiation (data not shown). But for each dose, number of apoptotic cells (including early apoptotic and late apoptotic cells) on day 8 was significantly more than that on day $6(\mathrm{p}<0.05)$ (Figure 3$)$.

\section{Effects of irradiation on ALP activity and mineralization of MC3T3-E1 cells}

ALP activity and von Kossa staining were performed on day 7 and day 14 after irradiation, respectively. The ALP activity of 0.5 Gy and 1.0 Gy groups was significantly increased than that of the control and 0.1 Gy groups $(\mathrm{p}<0.05)$. However, 0.1 Gy group had no

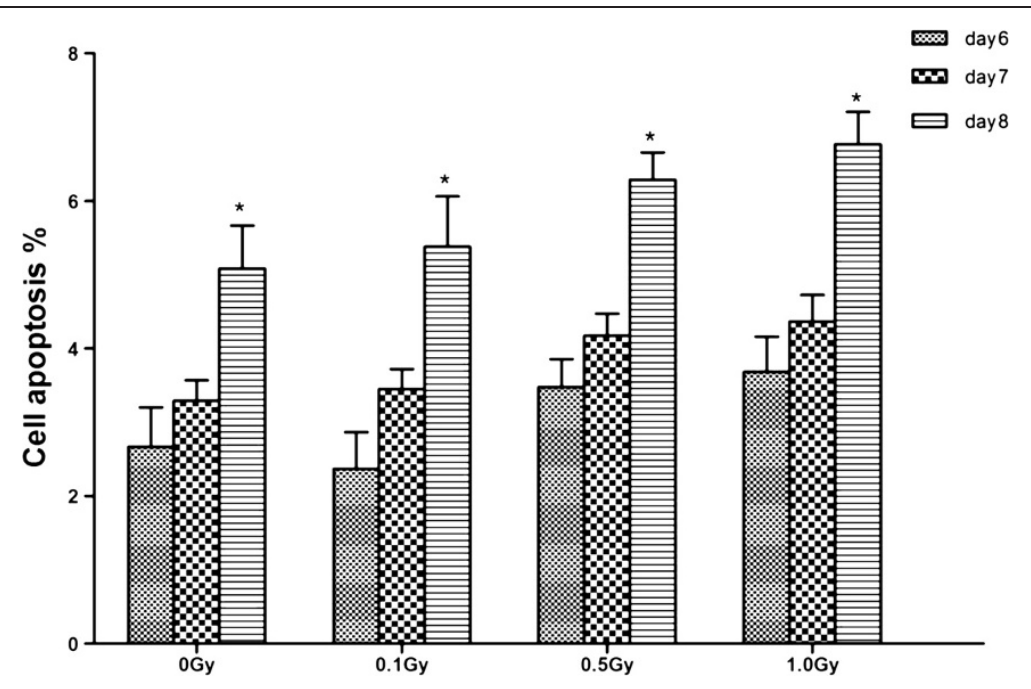

Figure 3 Apoptosis of irradiated MC3T3-E1 cells on day 6-8 after been seeded. MC3T3-E1 cells were exposed to 0, 0.1, 0.5, 1.0 Gy of X-irradiation. Cells on day 6-8 were double stained with annexin-V-FITC and PI and analyzed by flow cytometry. Data were expressed as the mean \pm SD of triplicate experiments $(n=3)$. For each dose, apoptosis cells (including early apoptotic and late apoptotic cells) was gradually increased from day 6 to day 8 and the number of apoptosis cell on day 8 was significantly more than that on day $6(p<0.05)$. 

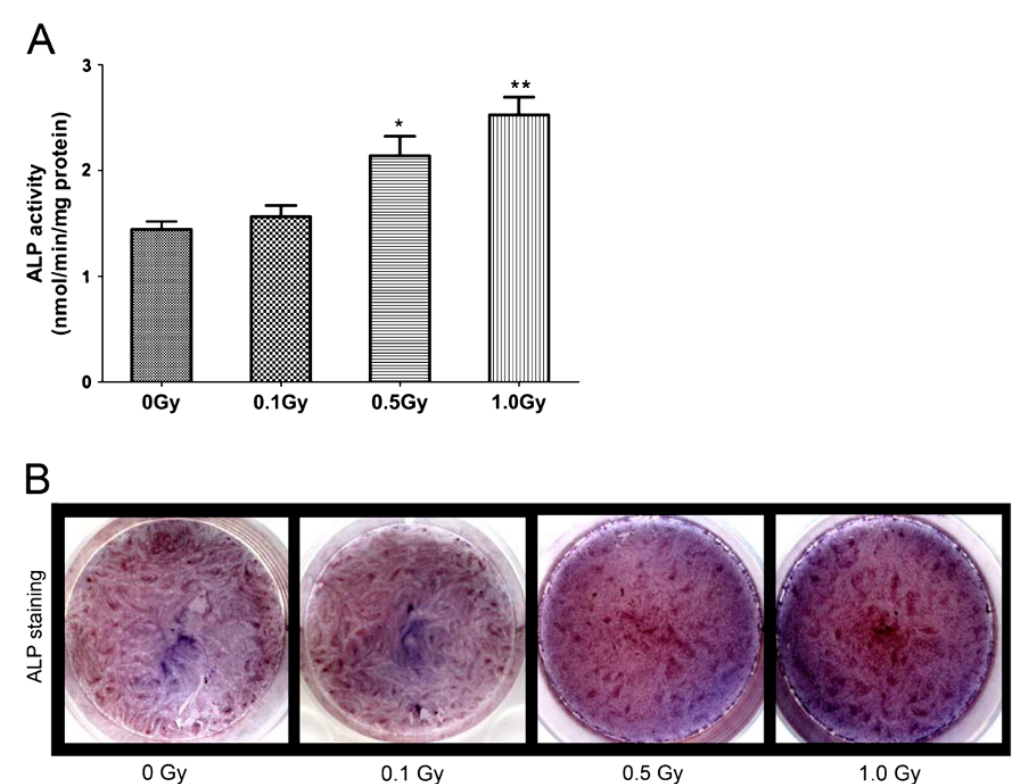

Figure 4 Effects of X-irradiation on ALP activity and staining of MC3T3-E1 cells. MC3T3-E1 cells were exposed to 0, 0.1, 0.5 and 1.0 Gy of X-irradiation respectively and cells were cultured for 7 days after irradiation. (A) ALP activity was measured and the data were expressed as mean $\pm S D(n=3)$. The ALP activity of 0.5 Gy and 1.0 Gy groups was significantly increased than that of the control group $(0 \mathrm{~Gy})\left({ }^{*} p<0.05\right.$, ${ }^{* *} \mathrm{p}<0.01$ ). However, $0.1 \mathrm{~Gy}$ groups had no significant difference compared with the control. (B) represented plate view of ALP staining. There were more positive cells in 0.5 and 1.0 Gy groups compared with the control.

significant difference compared with the control (Figure 4A). Similarly, ALP staining showed more positive cells (cytosol red coloration) in 0.5 Gy and 1.0 Gy groups compared with the control and 0.1 Gy groups (Figure $4 \mathrm{~B}$ ). von Kossa staining showed that the number of mineralized nodules in 0.5 Gy and 1.0 Gy group remarkably increased compared with the control group (p $<0.05$ ). The number of mineralized nodules had no significant difference between 0.1 Gy group and the control group (Figure 5A, B).

\section{Effects of irradiation on expression of $\mathrm{OCN}$ and $\mathrm{Cbfa} 1$}

To ascertain the effects of LDI on differentiation of MC3T3-E1 cells, we examined gene expression associated with osteoblast differentiation on day 10 after irradiation by real-time PCR. Real-time PCR showed

\section{A}
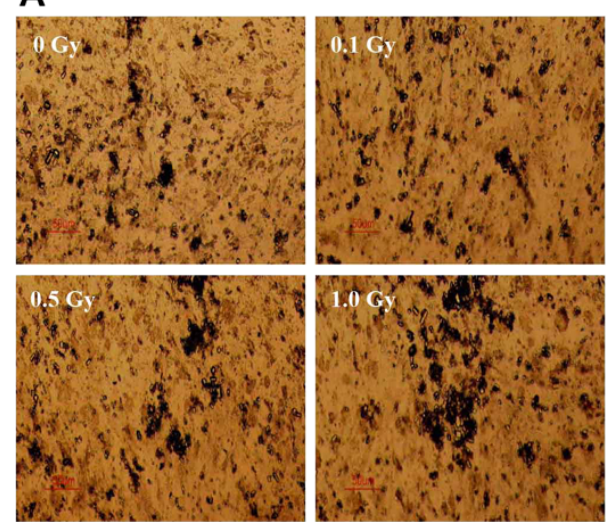

B

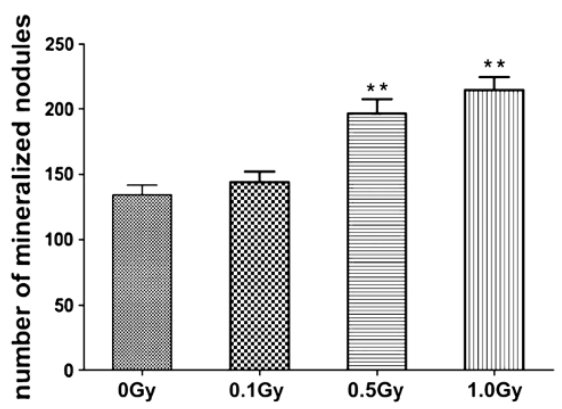

Figure 5 Effects of X-irradiation on mineralized nodules of MC3T3-E1 cells. MC3T3-E1 cells were exposed to 0, 0.1, 0.5 and 1.0 Gy of X-irradiation respectively and von Kossa staining was performed on day 14 after irradiation. A represented microscope images. The number of mineralized nodules of osteoblasts was counted and shown in B. Data were expressed as mean \pm SD of 3 wells. Significant difference in 0.5 and 1.0 Gy groups was observed compared with the control group (0 Gy) $\left.{ }^{* *} p<0.01\right)$. 

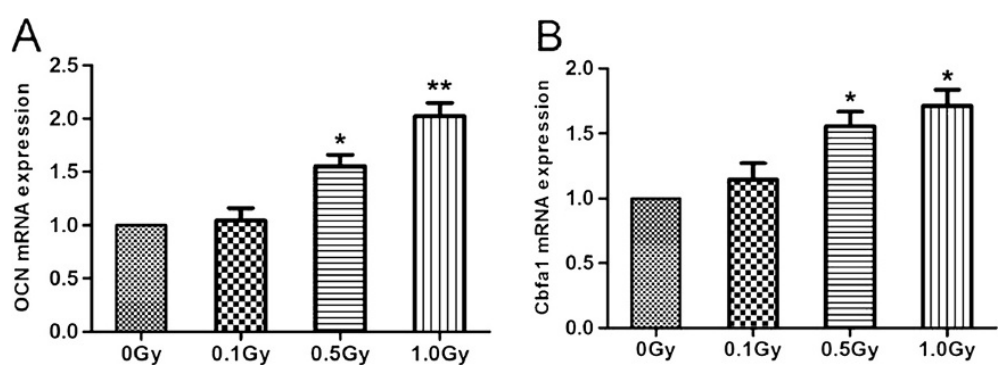

Figure 6 OCN, Cbfa1 mRNA expression of irradiated MC3T3-E1 cells. MC3T3-E1 cells were exposed to 0, 0.1, 0.5 and 1.0 Gy of X-irradiation respectively and cells were harvested on day 10 after irradiation. Total RNA was collected and real-time PCR was performed, $\beta$-actin as an endogenous control. Results were expressed as fold change over the control group (0 Gy). (A) OCN mRNA expression in 0.5 and 1 Gy groups were significantly increased compared with the control group $\left({ }^{*} \mathrm{p}<0.05,{ }^{* *} \mathrm{p}<0.01\right.$ ). (B) Cbfa1 mRNA expression in 0.5 and 1 Gy groups were significantly increased compared with the control group $\left({ }^{*} p<0.05\right)$.

mRNA expression of OCN and Cbfa1 was up-regulated after irradiation at 0.5 Gy and 1.0 Gy $(\mathrm{p}<0.05)$ (Figure 6A, B). To verify the results of mRNA expression of $\mathrm{OCN}, \mathrm{Cbf} \alpha 1$, we further analyzed the protein expression of OCN and Cbf 1 . OCN and Cbf 1 protein expression were generally consistent with their mRNA expression, and X-irradiation of 0.5 and 1 Gy resulted in obvious increase of protein level of OCN and $\mathrm{Cbf} \alpha 1$ $(\mathrm{p}<0.05)$ (Figure 7A, B).

\section{Discussion}

Various clinical and experimental investigations showed that irradiation could affect osteoblastic activity, including proliferation decrease, cell cycle arrest, increased sensitivity to apoptosis, and reduce of osteoblast differentiation, which was tightly associated with fracture union delay and osteoradionecrosis. However, radiation dose selected above was mainly moderate or high [16-24]. This study focused on effects of low dose X-irradiation on proliferation, differentiation and mineralization of osteoblasts (MC3T3E1 cells) in vitro.

Above all, we tried to determine the nontoxic doses of radiation on MC3T3-E1 osteoblastic cells. We found that cell proliferation measured by MTT and BrdU was significantly decreased when cells were exposed to $2.0 \mathrm{~Gy}$, which is consistent with some other studies [25,26], ruling out the possible severe toxicity of radiation used in the present study at low dose X-irradiation ( $\leq 1 \mathrm{~Gy})$.

Cell proliferation dropped significantly on Day 8. Coincidently, we found that cell apoptosis increased instead at this time. Furthermore, we considered that cell reached confluence and contact inhibition of cell-to-cell had initiated at this stage. On the other hand, cell proliferation decreased in 0.5 Gy and 1.0 Gy groups on Day 8 . MC3T3-E1 cells showed alkaline phosphatase activity here and began to differentiation. Some studies reported that proliferation activity was inversely related to differentiation of osteoblasts $[27,28]$. Thus, we supposed that proliferation decrease might be associated with their promoting cell differentiation.

It was widely accepted that ALP was the early phenotypic marker and in accordance with the differentiation of osteoblasts $[29,30]$. Formation of mineralized nodules was the ultimate expression of the osteogenic phenotype in vitro and the characteristic marker of mineralization [31]. Our results showed that ALP activity and mineralized nodules exposed to 0.1 Gy were not statistically different from those of nonirradiated group, which may
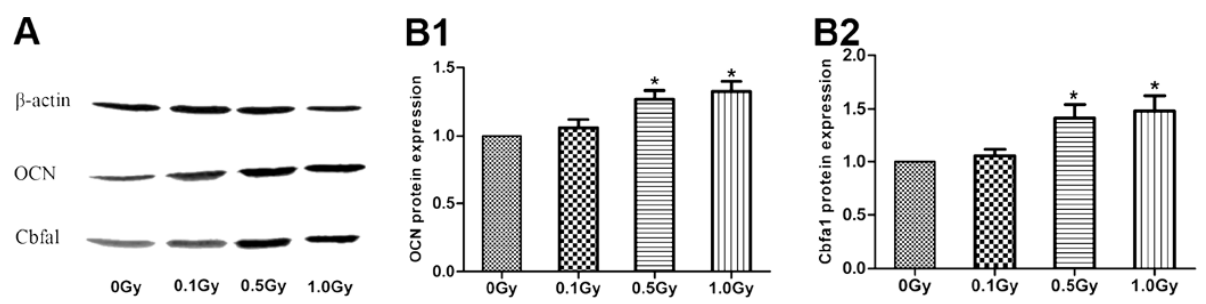

Figure 7 OCN, Cbfa1 protein expression of irradiated MC3T3-E1 cells. MC3T3-E1 cells were exposed to 0, 0.1, 0.5 and 1.0 Gy of X-irradiation respectively and cells were harvested on day 10 after irradiation. (A) The protein productions of OCN and Cbfa1 were detected by Western blot with $\beta$-actin as an endogenous control. (B) The quantitative date of OCN (B1) and Cbfa1 (B2) was band-density ratios compared to the control group. X-irradiation of 0.5 and 1 Gy resulted in obviously increase of protein level of OCN and Cbfa1 $\left({ }^{*} \mathrm{P}<0.05\right)$. 
represent a threshold effect for X-ray irradiation. But in LDI of 0.5 Gy and 1.0 Gy groups, ALP activity and mineralized nodules were positively correlated with the dosage of irradiation.

To further ascertain the effects of LDI on differentiation of MC3T3-E1 cells, we examined the expression of genes and proteins associated with osteoblastic differentiation. OCN was generally considered as a late marker in the mineralization stage, which bond with calcium and hydroxyapatite closely [32,33]. Our results showed that $\mathrm{OCN}$ expression was increased in 0.5 and 1.0 Gy groups compared with that of control. We also analyzed gene expression of collagen I. Surprisingly, no change was found in collagen I (data not shown). Wang reported that MC3T3 subclones with both high and low differentiation potential produced similar amounts of collagen in culture [34]. Variety of researches demonstrated that osteoblasts expressed the nuclear protein Cbfo1, which could act as a transcriptional factor and bind with certain cis-acting elements of $\mathrm{OCN}$ genes to further enhance their transcriptional activities $[35,36]$. The skeletal systems of the mice with a homozygous mutation in Cbf $\alpha 1$ showed a complete lack of ossification [37]. Cbfa1-deficient calvarial cells did not acquire osteoblastic phenotypes [38]. Thus, Cbf $\alpha 1$ was a critical gene not only for osteoblast differentiation but also for osteoblast function. Consequently, X-irradiation of 0.5 Gy and 1.0 Gy could increase the expression of Cbfo1, which might further activate the transcriptional activities of OCN in MC3T3-E1 cells.

Taking all results into consideration, low dose Xirradiation promoted differentiation of osteoblasts, but without impairing proliferation. As multipotential cells, mesenchymal stem cells (MSCs) could be induced into osteoblasts and had been long taken as important subjects of research. Among studies of moderate and high dose irradiation, some showed that radiation mainly suppressed the proliferation or cell cycle progression [39], while some showed that only the process of differentiation was suppressed $[40,41]$, as well as some showed that proliferation and differentiation of MSCs were both suppressed [42,43]. Multipotential cells are heterogeneous in differentiation potential and comprise both progenitors and relative mature cells. These controversial conclusions may be associated with MSCs themselves besides the diversity of radiation dose and research models.

Few available literature described the effects of lowdose irradiation on osteoblasts in vitro. Dare [44] reported that $\leq 400 \mathrm{mGy}$ of X-irradiation had no significant changes in proliferation and differentiation of MC3T3-E1 cells. Ahmad [26] showed $\leq 2$ Gy of 137Cs irradiator had no effects on proliferation and ALP activity of human fetal osteoblast 1.19 cells. Kurpinski [45] reported that 1 Gy X-ray perturbed DNA replication and DNA binding activity of MSCs, without impairing their osteogenic differentiation process in vitro. The discrepancy needed further study and the difference in radio sources, cell types and timing was also undoubtedly important like Kurpinski and Jin reported [45,46].

Interestingly, irradiation also induced terminal differentiation in some other culture systems, such as, human skin fibroblasts [47] and erythroid progenitor cells [48]. While some reported ionizing radiation greater than 2 Gy promoted osteoblasts terminal differentiation $[18,23]$. Different from the effects of moderate and high dose irradiation, LDI had no impacts on the process of proliferation of osteoblasts in our study. We thought that increasing differentiation of osteoblasts by LDI might be regarded as a kind of promotion of tissue repair on the condition that osteoblasts have the normal ability of proliferation. Furthermore, the more differentiated osteoblasts can help callus formation and callus calcification in vivo.

\section{Conclusion}

This study indicated that LDI could enhance the differentiation and mineralization of MC3T3-E1 cells, without affecting proliferation at the early stage. Thus we hypothesized that LDI would be beneficial for healing of injured bone tissues.

Fracture healing is a complex biologic phenomenon. We are aware of the limitations of an in vitro study and don't draw general conclusion only from a cell line (MC3T3-E1) cells. In addition, we examined the response of osteoblasts to single low dose irradiation in the current experimental study. Future studies may also be needed to consider clinical situation where radiation is delivered in a fractionated manner. Fractionated irradiation and mechanical study should be further designed for better understanding the effects of LDI on osteoblasts.

\section{Abbreviations \\ LDI: low dose irradiation; MTT: methylthiazoletetrazolium; \\ BrdU: bromodeoxyuridine; ALP: alkaline phosphatase; OCN: osteocalin; Cbfa1: core-binding factor a1.}

\section{Competing interests}

The study was supported by the nature science fund of Jiangsu Province in China (No. SBK200920031). The authors receive nothing of value and have no conflict of interest.

\section{Acknowledgments}

The authors acknowledge Prof. Qin Ling of the Chinese University of Hong Kong and Prof. Ye Tian of Soochow University for excellent technical support.

\section{Author details}

${ }^{1}$ Department of Orthopedics, The Second Affiliated Hospital of Soochow University, Suzhou 215004, China. ${ }^{2}$ Department of Biochemistry and Molecular Biology, School of Medicine, Soochow University, Suzhou 215123, China. 


\section{Authors' contributions}

All authors contributed to this study. WX made contribution in conception and design of the study, participated in carrying out the experiments. LX carried out the experiments, collected the data and made the statistical analysis. MC carried out the experiments and helped to draft the manuscript. YTM and ZGX participate in the design and coordination of the study. SLW gave intellectual support and revised critically the manuscript. QRD led the project, gave intellectual support and drafted the manuscript. All authors read and approved the final manuscript.

Received: 16 December 2011 Accepted: 8 June 2012

Published: 8 June 2012

\section{References}

1. Mitchell MJ, Logan PM: Radiation-induced changes in bone. Radiographics 1998, 18:1125-1136.

2. Gebhard FT, Kraus MD, Schneider E, Liener UC, Kinzl L, Arand M: Does computer-assisted spine surgery reduce intraoperative radiation doses? Spine 2006, 31:2024-2027.

3. Fitousi NT, Efstathopoulos EP, Delis HB, Kottou S, Kelekis AD, Panayiotakis GS: Patient and staff dosimetry in vertebroplasty. Spine 2006, 31:E884-E889.

4. Kirousis $\mathrm{G}$, Delis $\mathrm{H}$, Megas $\mathrm{P}$, Lambiris $\mathrm{E}$, Panayiotakis $\mathrm{G}$ : Dosimetry during intramedullary nailing of the tibia. Acta Orthop 2009, 80:568-572.

5. Zhou XZ, Zhang G, Dong QR, Chan CW, Liu CF, Qin L: Low-dose Xirradiation promotes mineralization of fracture callus in a rat model. Arch Orthop Trauma Surg 2009, 129:125-132.

6. Hofmann A, Ritz U, Hessmann MH, Schmid C, Tresch A, Rompe JD, Meurer A, Rommens PM: Cell viability, osteoblast differentiation, and gene expression are altered in human osteoblasts from hypertrophic fracture non-unions. Bone 2008, 42:894-906.

7. Laukkanen MO, Kuramoto K, Calmels B, Takatoku M, von Kalle C, Donahue RE, Dunbar CE: Low-dose total body irradiation causes clonal fluctuation of primate hematopoietic stem and progenitor cells. Blood 2005, 105:1010-1015,

8. Heissig B, Raffi S, Akiyama H, Ohki Y, Sato Y, Rafael T, Zhu Z, Hicklin DJ, Okumura K, Ogawa H, Werb Z, Hattori K: Low-dose irradiation promotes tissue revascularization through VEGF release from mast cells and MMP9-mediated progenitor cell mobilization. J Exp Med 2005, 202:739-750.

9. Yamasaki K, Hagiwara H: Excess iron inhibits osteoblast metabolism. Toxicol Lett 2009, 191:211-215.

10. Carmichael J, DeGraff WG, Gazdar AF, Minna JD, Mitchell JB: Evaluation of a tetrazolium-based semiautomated colorimetric assay: assessment of chemosensitivity testing. Cancer Res 1987, 47:936-942.

11. Kanazawa I, Yamaguchi T, Yano S, Yamauchi M, Yamamoto M, Sugimoto T: Adiponectin and AMP kinase activator stimulate proliferation, differentiation, and mineralization of osteoblastic MC3T3-E1 cells. BMC Cell Biol 2007, 8:51.

12. Xu Z, Choudhary S, Okada Y, Voznesensky O, Alander C, Raisz L, Pilbeam C: Cyclooxygenase-2 gene disruption promotes proliferation of murine calvarial osteoblasts in vitro. Bone 2007, 41:68-76.

13. Lowry OH, Roberts NR, Wu ML, Hixon WS, Crawford EJ: The quantitative histochemistry of brain. II. Enzyme measurements. J Biol Chem 1954, 207:19-37.

14. Bellows CG, Aubin JE, Heersche JN, Antosz ME: Mineralized bone nodules formed in vitro from enzymatically released rat calvaria cell populations. Calcif Tissue Int 1986, 3:143-154

15. Livak KJ, Schmittgen TD: Analysis of relative gene expression data using real-time quantitative PCR and the 2(-Delta Delta C(T)) Method. Methods 2001, 25:402-408.

16. Gal TJ, Munoz-Antonia T, Muro-Cacho CA, Klotch DW: Radiation effects on osteoblasts in vitro: a potential role in osteoradionecrosis. Arch Otolaryngol Head Neck Surg 2000, 126:1124-1128.

17. Gevorgyan A, La Scala GC, Sukhu B, Leung IT, Ashrafpour H, Yeung I, Neligan PC, Pang CY, Forrest CR: An in vitro model of radiation-induced craniofacial bone growth inhibition. J Craniofac Surg 2007, 18:1044-1050.

18. Matsumura S, Jikko A, Hiranuma H, Deguchi A, Fuchihata H: Effect of $x$-ray irradiation on proliferation and differentiation of osteoblasts. Calcif Tissue Int 1996, 59:307-309.

19. Evans $H B$, Brown $S$, Hurst $L N$ : The effects of early postoperative radiation on vascularized bone grafts. Ann Plast Surg 1991, 26:505-510.
20. Takahashi S, Sugimoto M, Kotoura Y, Sasai K, Oka M, Yamamuro T: Longterm changes in the haversian systems following high-dose irradiation, an ultrastructural and quantitative histomorphological study. J Bone Joint Surg Am 1994, 76:722-738.

21. Gevorgyan A, Sukhu B, Alman BA, Bristow RG, Pang CY, Forrest CR: Radiation effects and radioprotection in MC3T3-E1 mouse calvarial osteoblastic cells. Plast Reconstr Surg 2008, 122:1025-1035.

22. Dudziak ME, Saadeh PB, Mehrara BJ, Steinbrech DS, Greenwald JA, Gittes GK: The effects of ionizing radiation on osteoblast-like cells in vitro. Plast Reconstr Surg 2000, 106:1049-1061.

23. Matsumura S, Hiranuma H, Deguchi A, Maeda T, Jikko A, Fuchihata H: Changes in phenotypic expression of osteoblasts after $\mathrm{X}$ irradiation. Radiat Res 1998, 149:463-471.

24. Sakurai T, Sawada Y, Yoshimoto M, Kawai M, Miyakoshi J: Radiation-induced reduction of osteoblast differentiation in C2C12 cells. J Radiat Res 2007, 6:515-521.

25. Li J, Kwong DL, Chan GC: The effects of various irradiation doses on the growth and differentiation of marrow-derived human mesenchymal stromal cells. Pediatr Transplant 2007, 4:379-387.

26. Ahmad M, Sampair C, Nazmul-Hossain AN, Khurana N, Nerness A, Wutticharoenmongkol P: Therapeutic doses of radiation alter proliferation and attachment of osteoblasts to implant surfaces. J Biomed Mater Res A 2008, 86:926-934.

27. Stein GS, Lian JB, Stein JL, Wijnen AJV, Montecino M: Transcriptional control of osteoblast growth and differentiation. Physiol Rev 1996, 76:593-629.

28. Owen TA, Aronow M, Shalhoub V, Barone LM, Wilming L, Tassinari MS, Kennedy MB, Pockwinse S, Lian JB, Stein GS: Progressive development of the rat osteoblast phenotype in vitro: Reciprocal relationships in expression of genes associated with osteoblast proliferation and differentiation during formation of the bone extracellular matrix. I Cell Physiol 1990, 143:420-430.

29. Fukayama S, Tashjian AH Jr: Involvement of alkaline phosphatase in the modulation of receptor signaling in osteoblast: Evidence for a difference between human parathyroid hormone-related protein and human parathyroid hormone. J Cell Physiol 1994, 158:391-397.

30. Torii $Y$, Hitomi K, Yamagishi Y, Tsukagoshi N: Demonstration of alkaline phosphatase participation in the mineralization of osteoblasts by antisense RNA approach. Cell Biol Int 1996, 20:459-464.

31. Luppen CA, Leclerc N, Noh T, Barski A, Khokhar A, Boskey AL, Smith E, Frenkel B: Brief bone morphogenetic protein 2 treatment of glucocorticoid-inhibited MC3T3-E1 osteoblasts rescues commitmentassociated cell cycle and mineralization without alteration of Runx2. Biol Chem 2003, 278:44995-45003.

32. Hauschka PV, Lian JB, Cole DE, Gundberg CM: Osteocalcin and matrix Gla protein: Vitamin K-dependent proteins in bone. Physiol Rev 1989, 69:990-1047.

33. Christenson RH: Biochemical markers of bone metabolism: an overview. Clin Biochem 1997, 30:573-593.

34. Wang D, Christensen K, Chawla K, Xiao G, Krebsbach PH, Franceschi RT: Isolation and characterization of MC3T3-E1 preosteoblast subclones with distinct in vitro and in vivo differentiation/mineralization potential. $J$ Bone Miner Res 1999, 14:893-903.

35. Ducy P, Zhang R, Geoffroy V, Ridall AL, Karsenty G: Osf2/Cbfa1: A transcriptional activate or of osteoblast differentiation. Cell 1997, 89:747-754.

36. Xiao G, Cui Y, Ducy P, Karsenty G, Franceschi RT: Ascorbic acid-dependent activation of the osteocalcin promoter in MC3T3-E1 preosteoblasts: Requirement for collagen matrix synthesis and the presence of an intact OSE2 sequence. Mol Endocrinol 1997, 11:1103-1113.

37. Komori T, Yagi H, Nomura S, Yamaguchi A, Sasaki K, Deguchi K, Shimizu Y, Bronson RT, Gao YH, Inada M, Sato M, Okamoto R, Kitamura Y, Yoshiki S, Kishimoto T: Targeted disruption of Cbfa1 results in a complete lack of bone formation owing to maturational arrest of osteoblasts. Cell 1997, 89:755-764.

38. Kobayashi H, Gao Y, Ueta C, Yamaguchi A, Komori T: Multilineage differentiation of Cbfa1-deficient calvarial cells in vitro. Biochem Biophys Res Commun 2000, 273:630-636.

39. Ikeda S, Hachisu R, Yamaguchi A, Gao YH, Okano T: Radiation retards muscle differentiation but does not affect osteoblastic differentiation induced by bone morphogenetic protein- 2 in $\mathrm{C} 2 \mathrm{C} 12$ myoblasts. Int $\mathrm{J}$ Radiat Biol 2000, 76:403-411. 
40. Koelbl O, Knaus P, Pohl F, Flentje M, Sebald W: Radiationinduced reduction of BMP-induced proteoglycan synthesis in an embryonal mesenchymal tissue equivalent using the chicken "limb bud" test. Strahlenther Onkol 2001, 177:432-436.

41. Pohl F, Hassel S, Nohe A, Flentje M, Knaus P, Sebald W, Koelbl O: Radiationinduced suppression of the Bmp2 signal transduction pathway in the pluripotent mesenchymal cell line C2C12: An in vitro model for prevention of heterotopic ossification by radiotherapy. Radiat Res 2003, 159:345-350.

42. Kondo H, Limoli C, Searby ND, Almeida EA, Loftus DJ, Vercoutere W, MoreyHolton E, Giedzinski E, Mojarrab R, Hilton D, Globus RK: Shared oxidative pathways in response to gravity-dependent loading and gammairradiation of bone marrow-derived skeletal cell progenitors. Radiats Biol Radioecol 2007, 47:281-285

43. Li J, Kwong DLW, Chan GCF: The effects of various irradiation doses on the growth and differentiation of marrow-derived human mesenchymal stromal cells. Pediatr Transplant 2007, 11:379-387.

44. Dare A, Hachisu R, Yamaguchi A, Yokose S, Yoshiki S, Okano T: The Effects of ionizing radiation on proliferation and differentiation of osteoblast-like cells. J Dent Res 1997, 76:658-664.

45. Kurpinski K, Jang DJ, Bhattacharya S, Rydberg B, Chu J, So J, Wyrobek A, Li S, Wang D: Differential effects of x-rays and high-energy $56 \mathrm{Fe}$ ions on human mesenchymal stem cells. Int J Radiat Oncol Biol Phys 2009, 73:869-877.

46. Jin YW, Na YJ, Lee YJ, An S, Lee JE, Jung M, Kim H, Nam SY, Kim CS, Yang KH, Kim SU, Kim WK, Park WY, Yoo KY, Kim CS, Kim JH: Comprehensive analysis of time- and dose-dependent patterns of gene expression in a human mesenchymal stem cell line exposed to low-dose ionizing radiation. Oncol Rep 2008, 1:135-144.

47. Lara PC, Russell NS, Smolders IJ, Bartelink H, Begg AC, Coco-Martin JM: Radiation-induced differentiation of human skin fibroblasts: Relationship with cell survival and collagen production. Int J Radiat Biol 1996, 70:683-692.

48. Schwenke K, Peterson HP, von Wangenheim KH, Feinendegen LE: Radiation-enhanced differentiation of erythroid progenitor cells and its relation to reproductive cell death. Int J Radiat Biol 1996, 69:309-317.

doi:10.1186/1471-2474-13-94

Cite this article as: Xu et al:: The effects of low dose X-irradiation on osteoblastic MC3T3-E1 cells in vitro. BMC Musculoskeletal Disorders 2012 13:94.

\section{Submit your next manuscript to BioMed Central and take full advantage of:}

- Convenient online submission

- Thorough peer review

- No space constraints or color figure charges

- Immediate publication on acceptance

- Inclusion in PubMed, CAS, Scopus and Google Scholar

- Research which is freely available for redistribution 